\title{
Pain Associated with Heterotopic Ossification: Does It Have a Neurogenic Component as Well?
}

\section{TO THE EDITOR,}

Heterotopic ossification ( $\mathrm{HO}$ ) is the formation of the lamellar bone within the tissues where normally osseous tissue does not exist. Neurogenic $\mathrm{HO}$ is a frequent complication after spinal cord injury and traumatic brain injury and it is rarely seen after several neurologic disorders such as stroke, encephalitis, and multiple sclerosis (1). Pain, usually severe, is commonly associated with $\mathrm{HO}$ particularly in immature phases. Overall, $\mathrm{HO}$ is already a challenging condition, and pain associated with $\mathrm{HO}$ can result in a decreased quality of life (2).

Regarding the characteristics of the pain, nociceptive mechanisms already play an important role by insulting the adjacent soft tissues, causing inflammation, and triggering spasticity $(2,3)$. Concerning the etiology of $\mathrm{HO}$, neuropeptides, substance $\mathrm{P}$, calcitonin gene-related peptide, prostaglandins, and bone morphogenic protein can cause some sensory and sympathetic changes within the peripheral nerves. Moreover, Haran et al reported that $\mathrm{HO}$ tissue has some nerves (4). From this point of view, a neuropathic mechanism might cause pain in patients with HO. However, to the best of our knowledge, neuropathic pain in $\mathrm{HO}$ has not been studied yet. Any sort of nerve entrapments can be another cause of pain in $\mathrm{HO}$.

Non-steroidal anti-inflammatory drugs and bisphosphonates are the mainstay for the medical treatment of $\mathrm{HO}$ (5). Although non-steroidal anti-inflammatory drugs are taken in higher doses, pain remains a considerable problem in daily clinical practice. On the other hand, since the patients with $\mathrm{HO}$ have a neurologic insult (spinal cord injury, traumatic brain injury) as well, neuropathic pain can be attributed to these neurologic insults. As such, the possible neuropathic pain due to $\mathrm{HO}$ can easily be overlooked.

In short, herein we would like to draw attention to the fact that HO might cause neuropathic pain apart from nociceptive pain. However, the literature lacks sufficient data. Therefore, further studies concerning the association of neuropathic pain and morphologic and physiologic characteristics of the nerves in $\mathrm{HO}$ are awaited.

\author{
Timur Ekiz, MD \\ Ankara Physical Medicine and Rehabilitation \\ Training and Research Hospital \\ Ankara, Turkey \\ E-mail: timurekiz@gmail.com
}

Alparslan Yetisgin, MD

şanlıurfa Training and Research Hospital

şanlıurfa, Turkey

E-mail: dra_yetisgin@yahoo.com

\author{
Mustafa Turgut Yildizgoren \\ Assistant Professor \\ Mustafa Kemal University Medical School \\ Hatay, Turkey \\ E-mail: ftr.mustafaturgut@hotmail.com
}

Sule Sahin Onat, MD

Ankara Physical Medicine and

Rehabilitation Training and Research Hospital

Ankara, Turkey

E-mail: sahinsulester@gmail.com

\section{References}

1. Ekiz T, Özbudak Demir S, Dogan A, Özgirgin N. Coexistence of heterotopic ossification of the elbow and vitamin D deficiency following stroke: Can calcium and vitamin D treatment aggravate ossification? West Indian Med J doi: 10.7727/wimj.2014.076 [Epub ahead of print].

2. Yenigün D, Ekiz T, Nakipoglu Yüzer GF, Tasoglu Ö, Dogan-Aslan M, Özgirgin N. Severe pain, spasticity, and heterotopic ossification in a patient with spinal cord injury: A vicious circle and management eith baclofen pump. Pain Physician 2014 [in press].

3. Kara M, Ekiz T, Sarıkaya FG, Demir SÖ, Özçakar L. Severe bilateral heterotopic ossification in a patient with multiple sclerosis. Rehabil Nurs 2014; doi: 10.1002/rnj.162 [Epub ahead of print].

4. Haran M, Bhuta T, Lee B. Pharmacological interventions for treating acute heterotopic ossification. Cochrane Database Syst Rev 2004; 18:CDo03321.

5. Salisbury E, Sonnet C, Heggeness M, Davis AR, Olmsted-Davis E. Heterotopic ossification has some nerve. Crit Rev Eukaryot Gene Expr 2010; 20:313-324. 